\title{
Pengaruh Profitabilitas, Ukuran Perusahaan, dan Financial Leverage terhadap Praktik Perataan Laba (Income Smoothing) pada Perusahaan Farmasi yang Terdaftar di Bursa Efek Indonesia Periode 2011-2015
}

\author{
Azizah Fitriani \\ Program Studi Manajemen STIE Al-Anwar Mojokerto \\ e-mail: azizahfitriani@stie-alanwar.ac.id
}

\begin{abstract}
Abstrak
Penelitian ini bertujuan untuk menganalisis pengaruh profitabilitas, ukuran perusahaan, dan financial leverage terhadap praktik perataan laba (income smoothing) pada perusahaan farmasi yang terdaftar di Bursa Efek Indonesia periode 2011-2015. Data sekunder bersumber dari BEI. Sampel yang digunakan dalam penelitian ini sebanyak 8 perusahaan farmasi yang terdaftar di BEI, metode yang digunakan dalam penelitian ini adalah purposive yaitu metode pengambilan sampel dengan cara penetapan kriteria tertentu. Melalui penggunaan metode data poling tahun 2011-2015, maka total sampel (n) sebanyak 40. Teknik analisis data menggunakan uji regresi berganda dan uji $f$ dalam pengujian hipotesis. Hasil pengujian menunjukkan profitabilitas, ukuran perusahaan, dan financial leverage adalah signifikan terhadap praktik perataan laba. Kesimpulan dari penelitian ini adalah profitabilitas, ukuran perusahaan, dan financial leverage berpengaruh secara simultan terhadap perataan laba pada perusahaan farmasi yang terdaftar di BEI. Secara parsial, hanya ukuran perusahaan yang terbukti berpengaruh signifikan terhadap praktik perataan laba pada perusahaan farmasi yang terdaftar di BEI.
\end{abstract}

Kata kunci: Profitabilitas, ukuran perusahaan, financial leverage, perataan laba.

\section{PENDAHULUAN}

Laporan keuangan merupakan suatu pencerminan dari suatu kondisi perusahaan, karena di dalam laporan keuangan terdapat berbagai macam informasi yang dibutuhkan oleh berbagai pihak yang berkepentingan dengan perusahaan. Para pengguna laporan keuangan antara lain adalah manajemen, pemegang saham, kreditor, pemerintah, karyawan perusahaan, pemasok, konsumen dan masyarakat umum lainnya yang pada dasarnya dapat dibedakan menjadi dua kelompok besar, yaitu pihak internal dan eksternal. Laporan keuangan yang lengkap biasanya meliputi neraca, laporan laba rugi, laporan perubahan posisi keuangan (yang dapat disajikan dalam berbagai cara, misalnya sebagai laporan arus kas, atau laporan arus dana), catatan laporan keuangan. Disamping itu, skedul dan informasi tambahan yang berkaitan dengan laporan tersebut, seperti informasi keuangan segmen industri dan geografis serta pengungkapan pengaruh perubahan harga. Situasi ini didasari oleh manajemen terutama dari kalangan yang kinerjanya diukur berdasarkan informasi itu, sehingga mendorong timbulnya disfunctional behaviour. Adapun bentuk perilaku tidak semestinya yang timbul dalam hubungannya dengan laba adalah praktik perataan laba (income smoothing).

Koch dalam Suwito dan Arleen (2005) mendefinisikan perataan laba sebagai cara yang digunakan manajemen mengurangi fluktuasi laba yang dilaporkan agar sesuai dengan target yang diinginkan baik melalui metode akuntansi atau transaksi.

Perataan laba (income smoothing) sering dinyatakan apakah baik atau tidak, atau boleh atau tidak. Perataan laba baik dilakukan jika dalam pelaksanaannya tidak melakukan fraud. Tindakan perataan laba ini biasanya dilakukan untuk upaya mengurangi pajak, meningkatkan kepercayaan investor yang beranggapan laba yang bersifat stabil akan mengurangi kebijakan deviden yang stabil 
dan menjaga hubungan antara manajer dan pekerja untuk mengurangi gejolak kenaikan laba dalam pelaporan laba yang cukup tajam. Pada dasarnya praktik perataan laba ini telah dilakukan sejak lama dan oleh beberapa pihak masih dianggap wajar, yaitu selama perataan laba tersebut masih menggunakan metode akuntansi yang berlaku.

Diobservasi bahwa pada tahun 2012 mencapai 13\%, tahun 2013 tidak mengalami peningkatan ataupun penurunan, persentase pertumbuhan tetap sama di tahun sebelumnya yaitu 13\%. Pada tahun 2014 pertumbuhan perusahaan mengalam penurunan sebesar 5,8\% sehingga menjadi 7,2\%; dan tahun 2015 persentase pertumbuhan perusahaan menjadi meningkat tetapi hanya $0,9 \%$ menjadi $7,9 \%$. Pertumbuhan perusahaan farmasi dari tahun 2012 hingga 2015 sangat fluktuatif. Dengan keadaan pertumbuhan yang berfluktuatif, maka ada kemungkinan perusahaan akan melakukan perataaan laba (income smoothing).

Aji dan Mita (2010) menguji pengaruh profitabilitas, resiko keuangan, nilai perusahaan dan struktur kepemilikan terhadap praktik perataan laba memperoleh kesimpulan bahwa profitabilitas dan struktur kepemilikan tidak berpengaruh signifikan terhadap praktik perataan laba, nilai perusahaann dan resiko keuangan berpengaruh signifikan terhadap praktik perataan laba. Penelitian terdahulu menggunakan sampel perusahaan Manufaktur dan Keuangan di Bursa Efek Indonesia tahun 2006-2009; sedangkan pada penelitian ini menggunakan sampel Perusahaan Farmasi yang terdaftar di Bursa Efek Indonesia pada tahun 2011-2015.

Berdasarkan latar belakang masalah yang diuraikan, maka rumusan masalah penelitian ini adalah bagaimana pengaruh profitabilitas, ukuran perusahaan, dan financial leverage secara parsial maupun secara simultan terhadap praktik perataan laba (income smoothing) pada perusahaan farmasi yang terdaftar di Bursa Efek Indonesia selama periode 2011-2015. Tujuan dari penelitian ini adalah untuk menguji bagaimana pengaruh profitabilitas, ukuran perusahaan, dan financial leverage secara parsial maupun secara simultan terhadap praktik perataan laba (income smoothing) pada perusahaan farmasi yang terdaftar di Bursa Efek Indonesia selama periode 20112015.

\section{Teori Keagenan (Agency Theory)}

Pada penelitian ini digunakan pendekatan teori keagenen (agency theory) yang merupakan suatu pendekatan yang dapat menjabarkan konsep manajemen laba yang sangat terkait dengan praktik perataan laba. Teori keagenan (agency theory) menyatakan bahwa praktik perataan laba dipengaruhi oleh konflik kepentingan antara manajemen (agent) dan pemilik (principal) yang timbul ketika setiap pihak berusaha untuk mencapai atau mempertahankan tingkat kemakmuran yang dikehendakinya (Salno dan Baridwan, 2000). Dalam hal ini, pihak principal tidak memiliki informasi yang cukup tentang kinerja agent. Namun pihak agent mempunyai lebih banyak informasi mengenai kapasitas diri, lingkungan kerja, dan perusahaan secara keseluruhan. Hal inilah yang mengakibatkan ada ketidakseimbangan informasi yang dimiliki oleh principal dan agent.

\section{Profitabilitas}

Menurut Sartono (2010), profitabilitas adalah kemampuan perusahaan memperoleh laba dalam hubungannya dengan penjualan, total aktiva, maupun modal sendiri. Dengan demikian, bagi investor jangka panjang akan sangat berkepentingan dengan analisis profitabilitas ini, misalnya bagi pemegang saham akan melihat keuntungan yang akan benar-benar diterimanya dalam bentuk dividen. Profitabilitas merupakan salah satu indikator yang penting untuk menilai suatu perusahaan. Selain digunakan sebagai alat untuk mengukur kemampuan perusahaan dalam menghasilkan laba, profitabilitas juga dapat digunakan untuk mengetahui efektifitas perusahaan dalam mengelola sumber-sumber yang dimilikinya.

Rasio profitabilitas dalam penelitian ini diukur dengan menggunakan Return On Asset (ROA). ROA adalah perbandingan antara laba 
setelahpajak dengan Total Aset (Sartono, 2010). ROA merupakan ukuran penting untuk menilai sehat atau tidaknya perusahaan, yang mempengaruhi investor untuk membuat keputusan, dengan rumus (Sudana, 2011:23):

$$
R O A=\frac{\text { Earning After Taxes }}{\text { Total asset }}
$$

Perusahaan yang memiliki ROA yang lebih tinggi cenderung melakukan tindakan perataaan laba dibandingkan dengan perusahaan yang memiliki ROA lebih rendah. Hal ini karena manajemen dipandang tahu akan kemampuan untuk mendapatkan laba pada masa mendatang sehingga memudahkan dalam menunda atau mempercepat laba (Dewi \& Prasetiono, 2012).

\section{Ukuran Perusahaan}

Ukuran perusahaan adalah skala untuk menentukan besar kecilnya perusahaan. Ukuran perusahaan dihitung dengan menggunakan logaritma natural dari total aktiva, sehingga dapat dirumuskan sebagai berikut (Budiasih, 2009):

\section{Ukuran perusahaan $=L n$ Total Aktiva}

Interpretasi hasil adalah semakin besar total aktiva, maka semakin tinggi pula manajemen dalam melakukan praktik perataan laba.

\section{Financial Leverage}

Financial leverage menunjukkan proporsi atas penggunaan utang untuk membiayai investasinya. Perusahaan yang tak mempunyai leverage berarti menggunakan modal sendiri $100 \%$. Financial leverage dihasilkan dari total hutang dibagi total modal aktiva. Skala pengukuran yang digunakan adalah skala rasio dengan rumus (Sartono, 2010):

$$
\text { Debt Ratio }=\frac{\text { Total Hutang }}{\text { Total aktiva }}
$$

Rasio-rasio leverage menunjukkan besarnya modal yang berasal dari pinjaman (modal asing) yang dipergunakan untuk membiayai investasi dan operasional perusahaan. Sumber yang berasal dari modal asing akan meningkatkan resiko perusahaan.
Oleh karena itu, makin banyak menggunakan modal asing maka besar pula rasio leveragenya dan berarti semakin besar pula resiko yang dihadapi perusahaan. Sehingga semakin tinggi financial laverage, semakin tinggi manajemen melakukan praktik perataan laba.

\section{Perataan Laba}

Perataan laba adalah upaya yang sengaja dilakukan untuk memperkecil atau fluktuasi pada tingkat laba yang dianggap normal bagi suatu perusahaan. Dalam pengertian ini, perataan merepresentasi suatu bagian upaya manajemen perusahaan untuk mengurangi variasi tidak normal dalam laba pada tingkat yang diijinkan oleh prinsipprinsip akuntansi dan manajemen yang sehat (Beidelman, 1973 dalam Belkaoui, 2006). Perataan laba yang diukur dalam bentuk indeks Eckel (1981) yang merupakan variabel dummy dimana kelompok usaha yang melakukan income smoothing diberi nilai 1, sedangkan jika tidak diberi nilai 0 . Indeks Eckel dihitung dengan menggunakan rumus (Suryandari, 2012):

$$
\text { Index Income smoothing }=\frac{C V \Delta I}{C V \Delta S}
$$

dimanaCV $\Delta \mathrm{I}$ adalah koefisien variasi untuk perubahan laba bersih; $\mathrm{CV} \Delta \mathrm{S}$ adalah koefisien variasi untuk perubahan penjualan; $\Delta \mathrm{I}$ adalah perubahan laba bersih dalam satu periode; $\Delta S$ adalah perubahan penjualan dalam satu periode; dan, CV adalah koefisien variasi dari variabel yaitu standar devisiasi dibagi nilai yang diharapkan. CV $\Delta \mathrm{I}$ dan $\mathrm{CV} \Delta \mathrm{S}$ dapat dihitung sebagai berikut:

$$
\frac{\sqrt{\frac{\sum(\Delta X-\Delta \bar{x})^{2}}{n-1}}}{\Delta \bar{x}}
$$

Ada beberapa tujuan dari perataan laba, yaitu: (1)mencapai keuntungan pajak; (2)untuk memberi kesan baik dari pemilik dan kreditor terhadap kinerja manajemen; (3)mengurangi fluktuasi pada pelaporan laba dan mengurangi risiko, sehingga harga sekuritas yang tinggi dapat menarik perhatian pasar; (4)untuk menghasilkan pertumbuhan 
profit yang stabil; serta, (5)untuk menjaga posisi atau kedudukan mereka dalam perusahaan.

Dimensi perataan laba pada dasarnya adalah cara yang digunakan untukmelakukan perataan laba. Barnea et al. (1976 dalam Belkaoui, 2006) membedakan perataan laba ke dalam tiga dimensi, yaitu:

a. Perataan melalui terjadinya peristiwa dan atau pengakuan pihak manajemen dapat menentukan terjadinya aktivitas transaksi sedemikian rupa sehingga pengaruhnya terhadap laba yang dilaporkan cenderung memperkecil variasinya antar waktu. Sebagian besar penentuan waktu terjadinya peristiwa yang direncanakan (misalnya, riset dan pengembangan) akan merupakan fungsi dari aturan akuntansi yang mengatur tentang pengakuan akuntansi terhadap peristiwa-peristiwa tersebut.

b. Perataan melalui alokasi antar waktu. Dalam kaitannya dengan terjadinya dan pengakuan terhadap suatu peristiwa, pihak manajemen memiliki kebebasan yang lebih untuk mengendalikan penentuan periodeperiode yang akan dipengaruhi oleh kuantifikasi peristiwa-peristiwa tersebut.

c. Perataan melalui klasifikasi (perataan klasifikasi). Ketika statistik laporan keuangan selain net income (nilai selisih bersih semua pendapatan dan biaya) merupakan obyek perataan, manajemen dapat mengklasifikasi item-item laporan laba untuk mengurangi variasi antar waktu dalam statistik tersebut.

Teknik perataan laba yang bisa dilakukan ada beberapa cara, yaitu:

a. Memanfaatkan peluang untuk membuat estimasi akuntansi. Cara manajemen untuk mempengaruhi laba melalui judgement terhadap estimasi akuntansi, antara lain estimasi tingkat tidak tertagih, estimasi kurun waktu depresiasi aktiva tetap atau amortisasi aktiva tidak berwujud dan estimasi biaya garansi.

b. Mengubah metode akuntansi. Perubahan metode akuntansi yang digunakan untuk mencatat suatu transaksi. c. Menggeser periode biaya atau pendapatan. Beberapa orang menyebut rekayasa ini sebagai manipulasi keputusan operasional.

Sasaran dilakukannya praktik perataan laba adalah sebagai berikut:

1) Unsur penjualan, meliputi:

a. Pembuatan faktur, contohnya dengan membuat faktur dan mengakuinya sebagai penjualan periode sekarang, meskipun sebenarnya merupakan penjualan pada masa mendatang.

b. Penurunan (Downgrading) produk, contohnya dengan mengklasifikasikan produk yang belum rusak ke dalam kelompok produk rusak dan dilaporkan dengan harga yang lebih rendah dari yang sebenarnya.

2) Unsur biaya, meliputi:

a. Memecah-mecah faktur, contohnya: suatu faktur pembelian dijadikan beberapa faktur dengan tanggal yang berbeda dan dilaporkan dalam beberapa periode akuntansi.

b. Mencatat prepayment (biaya dibayar di muka sebagai biaya), contohnya: mengakui suatu biaya dibayar di muka untuk tahun depan sebagai biaya dalam tahun yang bersangkutan.

\section{Kerangka Pikir dan Hipotesis}

Penelitian ini meneliti hubungan antara profitabilitas, ukuran perusahaan, dan financial leverage terhadap praktik perataan laba sebagai variabel independen dan harga saham sebagai variabel dependen. Dari ketiga variabel tersebut dilakukan pengujian apakah mempunyai pengaruh terhadap praktik perataan laba, baik secara parsial maupun simultan. Hubungan antara variabel independen terhadap variabel dependen dapat dijelaskan sebagai berikut.

\section{Pengaruh Profitabilitas terhadap Praktik Perataan Laba}

Profitabilitas yaitu komponen laporan keuangan perusahaan yang bertujuan menilai kinerja manjemen, membantu pelaksanaan eestimasi kemampuan laba yang representatif dalam jangka panjang dan menaksir resiko dalam investasi atau meminjamkan dana 
(Adiningsih 2014). Dengan kata lain, profitabilitas menjadi tolok ukur kinerja bagi pihak eksternal. Profitabilitas dapat dijadikan patokan oleh investor maupun kreditor dalam menilai sehat atau tidaknya perusahaan. Profitabilitas perusahaan juga bisa digunakan untuk mengukur kemampuan perusahaan dalam memperoleh laba dan mengetahui efektivitas perusahaan dalam mengelola resources yang dimiliki.

Faktor profitabilitas menggunakan rasio Return on Total Assets (ROA). Analisis ROA merupakan salah satu bentuk rasio profitabilitas yang digunakan untuk mengukur kemampuan perusahaan dengan keseluruhan dana yang ditanamkan dalam aset yang digunakan untuk operasi perusahaan dalam menghasilkan keuntungan. Profitabilitas di ukur menggunakan ROA yang dihasilkan dari hasil bagi laba bersih perusahaan terhadap total aset (Sudana, 2011).

$\mathbf{H}_{1}$ : Profitabilitas berpengaruh signifikan terhadap praktik perataan laba.

\section{Pengaruh Ukuran perusahaan terhadap Praktik Perataan Laba}

Variabel yang digunakan untuk mengukur besarnya perusahaan adalah total aset. Sartono (2010 dalam Adiningsih, 2014) mengatakan besaran perusahaan atau skala perusahaan adalah ukuran perusahaan yang ditentukan dari jumlah total aset yang dimiliki oleh perusahaan. Dalam hal ini, total aset merupakan total sumber daya ekonomis yang digunakan perusahaan dalam menjalankan usahanya.

Salah satu perusahaan yang memiliki total aset yang besar akan mendapat perhatian lebih dari pihak luar, diantaranya pemerintah. Pemerintah relatif cenderung membebankan berbagai biaya yang dianggap sesuai dengan kemampuan perusahaan. Konsekuensinya, perusahaan besar juga diperkirakan akan menghindari fluktuasi laba yang terlalu drastis, sebab kenaikan laba yang drastis akan menyebabkan bertambahnya beban pajak. Sebaliknya, penurunan laba yang drastis akan memberi pandangan yang kurang baik. Maka perusahaan besar diperkirakan memiliki kecenderungan lebih besar untuk melakukan tindakan perataan laba.

$\mathbf{H}_{2}$ : Ukuran perusahaan berpengaruh secara siginfikan terhadap praktik perataan laba.

\section{Pengaruh Financial Leverage terhadap Praktik Perataan Laba}

Financial Leverage menunjukkan proporsi atas penggunaan utang untuk membiayai investasinya. Perusahaan yang tidak memiliki leverage berarti menggunakan modal sendiri $100 \%$, financial leverage dihasilkan dari total hutang dibagi dengan total aset (Sartono, 2010).

Rasio leverage menunjukkan besarnya modal yang berasal dari pinjaman (modal asing) yang dipergunakan untuk membiayai investasi dan operasional perusahaan. Sumber yang berasal dari modal asing akan meningkatkan resiko perusahaan. Oleh karena itu, makin banyak menggunakan modal asing maka besar pula rasio leverage-nya dan berarti semakin besar pula resiko yang dihadapi perusahaan. Sehingga semakin tinggi financial laverage, semakin tinggi manajemen melakukan praktik perataan laba.

$\mathbf{H}_{3}$ : Financial Leverage berpengaruh secara signifikan terhadap praktik perataan laba

Terakhir, dalam penelitian ini dilakukan pengujian pengaruh secara simultan dari variabel-variabel bebas terhadap variabel terikat.

$\mathbf{H}_{4}$ : Profitabilitas, ukuran perusahaan, dan financial leverage berpengaruh secara signifikan terhadap praktik perataan laba.

\section{METODE PENELITIAN}

Metode pengumpulan data dalam penelitian ini menggunakan dokumentasi yaitu teknik pengumpulan data yang diperoleh dari laporan publikasi BEI di www.idx.co.id. Indonesian Capital Market Directory (ICDM) yang berupa laporan keuangan, laporan tahunan (annual report).

Data yang digunakan dalam proses perhitungan adalah data kuantitatif, yaitu data yang bersumber dari data sekunder, yaitu 
sumber data yang tidak memberi informasi secara langsung kepada pengumpul data.

Variabel-variabel yang digunakan dalam penelitian ini terdiri dari variabel dependen (variabel terikat) yaitu Praktik Perataan Laba, dan variabel independen (variabel bebas) yaitu Profitabiltas, Ukuran Perusahaan, dan Financial Leverage.

Metode analisis data yang digunakan dalam penelitian ini adalah, analisis regresi linier berganda.Pengolahan dan analisis data dilakukan dengan menggunakan bantuan program SPSS versi 21 for Windows. Analisis regresi berganda dilakukan setelah melakukan pengujian asumsi klasik terlebih dahulu dan selanjutnya pengujian hipotesis. Pengujian asumsi klasik yang dilakukan mencakup ujiuji normalitas, autokorelasi, heterokedastisitas dan multikolinieritas.

\section{Analisis Regresi dan Uji Hipotesis}

Analisis regresi berganda dilakukan untuk mengetahui bagaimana hubungan antara variabel bebas (X) dengan variabel terikat (Y), dengan rumus (Sugiyono, 2011):

$$
\mathrm{Y}=\mathrm{a}+\beta 1 \mathrm{X}_{1}+\beta 2 \mathrm{X}_{2}+\beta 3 \mathrm{X}_{3}
$$

dimana $\mathrm{Y}$ adalah harga saham, $\mathrm{X}_{1}$ adalah profitabilitas, $\mathrm{X}_{2}$ adalah ukuran perusahaan, dan $\mathrm{X}_{3}$ adalah financial leverage.

Dalam pengujian hipotesis, dilakukan pengujian secara parsial menggunakan uji $t$, pengujian secara simultan menggunakan uji $F$, dan analisis koefisien determinasi $\left(\mathrm{R}^{2}\right)$.

\section{HASIL ANALISIS}

\section{Uji Normalitas}

Uji normalis dilakukan untuk menguji apakah distribusi data normal atau tidak dapat dilakukan dengan melihat nilai signifikasi uji
Kolmogorov-Smirnov (K-S).Salah satu uji statistik yang dapat digunakan untuk menguji normalitas residual adalah uji statistik nonparametrik Kolmogorov-Smirnov. Jika hasil uji menunjukkan nilai Sig. $>0,05$ maka data residual dinilai terdistribusi dengan normal; sebaliknya, jika hasil uji menunjukkan nilai Sig. $<0,05$ maka data residual terdistribusi tidak normal (Ghozali, 2016).

Dari hasil pengujian dalam penelitian ini dapat disimpulkan nilai KolmogorovSmirnov untuk variabel-variabel profitabilitas, ukuran perusahaan dan financial leverage adalah sebesar 1,096 dan signifikasi residual $0,180>0,05$ yang artinya membuktikan bahwa data residual berdistribusi normal.

\section{Uji Multikolinearitas}

Multikolinieritas yaitu ada hubungan yang kuat di antara beberapa atau semua variabel bebas pada model regresi. Jika terdapat multikolinieritas maka koefisien regresi dinilai menjadi tidak tentu, tingkat kesalahannya menjadi sangat besar dan biasanya ditandai dengan nilai koefisien determinasi yang sangat besar. Tetapi pada pengujian parsial koefisien regresi, tidak ada ataupun kalau ada sangat sedikit sekali koefisien regresi yang signifikan. Pada penelitian ini digunakan nilai variance inflation factors (VIF) sebagai indikator kondisi multikolinieritas antar variabel bebas.

Multikolinearitas juga dilihat dari nilai toleran dan Variance InflationFactor atau VIF. Nilai cut-off yang umum dipakai adalah nilai toleran $>0,10$ atau sama. Nilai VIF diatas 10 sehingga data yang tak terkena mulkolinearitas nilai toleransinya harus lebih dari 0,10 atau VIF kurang dari 10.

Tabel 1. Hasil Uji Multikolinieritas, Analisis Regresi dan Uji $t$

\begin{tabular}{|c|c|c|c|c|c|c|c|}
\hline \multicolumn{8}{|c|}{ Coefficients $^{a}$} \\
\hline \multirow[t]{2}{*}{ Model } & \multicolumn{2}{|c|}{$\begin{array}{l}\text { Unstandardized } \\
\text { Coefficients }\end{array}$} & \multirow{2}{*}{$\begin{array}{c}\text { Standardized } \\
\text { Coefficients } \\
\text { Beta }\end{array}$} & \multirow[b]{2}{*}{$\mathrm{t}$} & \multirow[b]{2}{*}{ Sig. } & \multicolumn{2}{|c|}{ Collinearity Statistics } \\
\hline & B & Std. Error & & & & Tolerance & VIF \\
\hline (Constant) & $-210,874$ & 126,747 & & $-1,664$ & 105 & & \\
\hline Profitabilitas & 99,931 & 132,560 & ,185 & ,754 & ,456 & ,369 & 2,707 \\
\hline 1 Ukuran Perusahaan & 15,404 & 7,123 & ,332 & 2,163 & ,037 & ,942 & 1,062 \\
\hline Financial Laverage & $-71,296$ & 131,616 &,- 133 &,- 542 & ,591 & ,366 & 2,731 \\
\hline
\end{tabular}

Sumber: Data sekunder (diolah), Tahun 2017. 


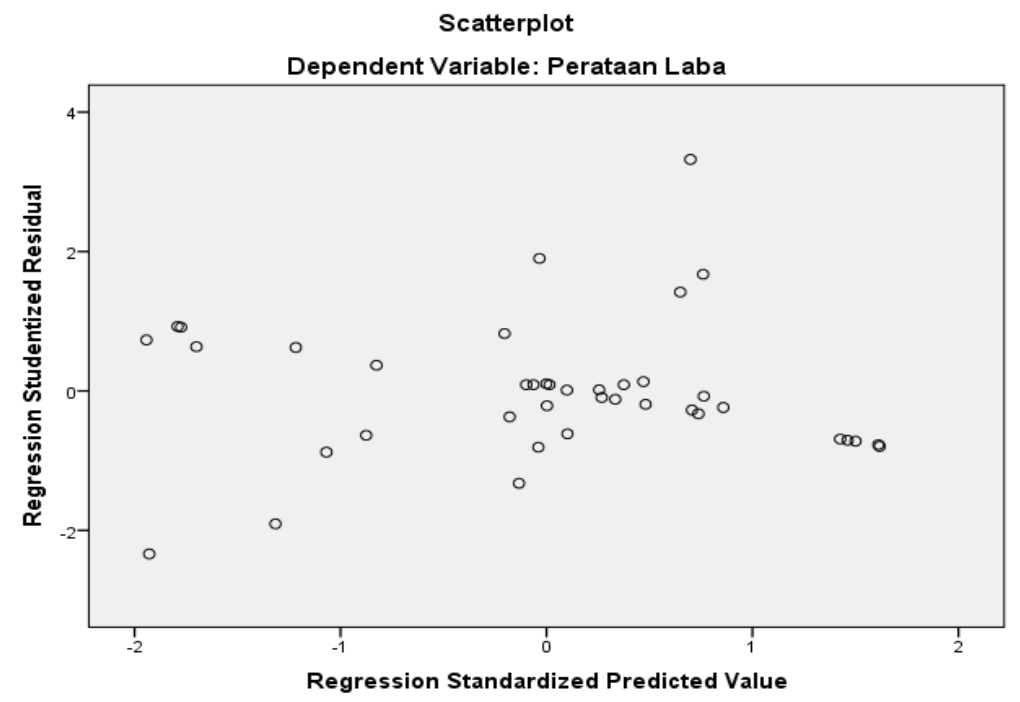

Sumber: Data sekunder (diolah), Tahun 2017.

\section{Gambar 1. Hasil Uji Heteroskedastisitas}

Tabel 2. Hasil UjiAutokorelasi dan Koefisien Determinasi

\begin{tabular}{c|r|r|r|r|r}
\hline \multicolumn{1}{c}{ Model Summary $^{\mathbf{0}}$} \\
\hline Model & $\mathrm{R}$ & \multicolumn{1}{|c|}{ R Square } & Adjusted R Square & $\begin{array}{c}\text { Std. Error of the } \\
\text { Estimate }\end{array}$ & \multicolumn{1}{c}{ Durbin-Watson } \\
\hline 1 &, $451^{\mathrm{a}}$ &, 203 &, 137 & 56,61202 & 1,818 \\
\hline
\end{tabular}

Sumber: Data sekunder (diolah), Tahun 2017.

Berdasarkan Tabel 1 diperoleh bahwa tidak ada satu variabel bebas yang memiliki nilai VIF lebih dari 10. Oleh karena itu dapat disimpulkan tidak ada multikolinearitas antara variabel dalam model regresi.

\section{Uji Heterokedastisitas}

Uji Heteroskedastisitas bertujuan menguji apakah dalam model regresi terjadi ketidak-samaan variance dari residual satu pengamatan ke pengamatan lain. Model regresi yang baik adalah yang tidak terjadi heteroskedasitas. Pengujian untuk melihat ada atau tidaknya Heteroskedisitas bisa dilakukan dengan melihat scatter plot antara nilai prediksi variabel terikat (SRESID) dengan residual (ZPRED). Jika titik-titik pada scatter plot tersebut membentuk pola tertentu yang teratur (misalnya, bergelombang, melebar kemudian menyempit), maka diindikasikan telah terjadi heteroskedastisitas.

Berdasarkan Gambar 1 dapat dilihat bahwa data tersebar secara acak di atas dan di bawah angka 0 (nol) pada sumbu Y, maka dapat disimpulkan bahwa data penelitian tersebut tidak terdapat heterokedastisitas, namun untuk penyebarannya kurang baik.

\section{Uji Autokorelasi}

Autokorelasi didefinisikan sebagai korelasi antar observasi yang diukur berdasarkan deret waktu dalam model regresi; atau dengan kata lain, error dari observasi tahun berjalan dipengaruhi oleh error dari observasi tahun sebelumnya. Pengujian autokorelasi memakai uji Durbin-Watson untuk mengetahui ada tidaknya autokorelasi pada model regresi dan berikut nilai DurbinWatson yang diperoleh melalui hasil estimasi model regresi.

Tabel 2 menunjukkan hasil pengujian autokorelasi bahwa nilai Durbin Watson sebesar 1,818. Berdasarkan tabel $\mathrm{n}=40, \mathrm{~K}=$ 3 , diperoleh nilai Durbin-Watson tersebut berada di antara nilai du $=1,6589$ dan 4 -du $=$ 2,182; hasil ini menunjukkan tidak adanya masalah autokorelasi. 


\section{Analisis Regresi Linier Berganda}

Berdasarkan Tabel 1, hasil pengolahan data menunjukkan persamaan regresi linier berganda untuk penelitian ini sebagai berikut:

$$
\begin{aligned}
\mathrm{Y}= & -210,874+99,932 \mathrm{X}_{1}+15,404 \mathrm{X}_{2}- \\
& 71,296 \mathrm{X}_{3}
\end{aligned}
$$

Dari persamaan itu dapat dijelaskan pengaruh dari masing-masing variabel bebas terhadap variabel terikat. Persamaan regresi menunjukkan bahwa koefisien regresi untuk profitabilitas $\left(b_{1}\right)$ dan ukuran perusahaan $\left(b_{2}\right)$ bernilai positif. Hasil ini menunjukkan bahwa jika salah satu dari kedua variabel bebas tersebut mengalami kenaikan atau penurunan, dengan asumsi variabel bebas yang lain tidak mengalami perubahan, maka praktik perataan laba juga mengalami kenaikan/penurunan.

Persamaan regresi juga menunjukkan bahwa koefisien regresi untuk financial leverage $\left(b_{3}\right)$ bernilai negatif. Hasil ini menunjukkan bahwa jika financial leverage sebagai variabel bebas mengalami kenaikan/ penurunan, dengan asumsi variabel bebas yang lain tidak mengalami perubahan, maka sebaliknya praktik perataan laba mengalami penurunan/kenaikan.

\section{Pengujian Hipotesis}

Berdasarkan Tabel 1, hasil uji hipotesis secara parsial (uji $t$ ) terkait derajat signifikansi dari hubungan masing-masing variabel bebas terhadap variabel terikat adalah sebagai berikut.

Untuk hubungan antara profitabilitas dan praktik perataan laba diperoleh nilai $t_{\text {hitung }}$ sebesar 0,754 dan tingkat signifikansi (Sig. $t$ ) sebesar 0,456. Karena nilai Sig. $t$ lebih besar dari $0,05(\alpha)$ maka $\mathrm{H}_{\mathrm{o}}$ diterima dan $\mathrm{H}_{\mathrm{a}}$ ditolak. Hasil ini menunjukkan tidak terdapat pengaruh parsial signifikan oleh profitabilitas terhadap praktik perataan laba. Dengan demikian, hipotesis pertama $\left(\mathrm{H}_{1}\right)$ ditolak atau tidak terbukti kebenarannya.

Untuk hubungan antara ukuran perusahaan dan praktik perataan laba diperoleh nilai $t_{\text {hitung }}$ sebesar 2,163 dan tingkat signifikansi (Sig. t) sebesar 0,037. Karena nilai Sig. t lebih kecil dari 0,05 $(\alpha)$ maka $\mathrm{H}_{\mathrm{o}}$ ditolak dan $\mathrm{H}_{\mathrm{a}}$ diterima. Hasil yang diperoleh ini menunjukkan terdapat pengaruh parsial yang signifikan oleh ukuran perusahaan terhadap praktik perataan laba.Dengan demikian, hipotesis kedua $\left(\mathrm{H}_{2}\right)$ diterima atau terbukti kebenarannya.

Untuk hubungan antara financial leverage dan praktik perataan laba diperoleh nilai $t_{\text {hitung }}$ sebesar $-0,542$ dan tingkat signifikansi (Sig. $t$ ) sebesar 0,591. Karena nilai Sig. $t$ lebih besar dari 0,05 $(\alpha)$ maka $\mathrm{H}_{\mathrm{o}}$ diterima dan $\mathrm{H}_{\mathrm{a}}$ ditolak. Hasil yang diperoleh ini menunjukkan tidak terdapat pengaruh parsial yang signifikan oleh financial leverage terhadap praktik perataan laba. Dengan demikian, hipotesis ketiga $\left(\mathrm{H}_{3}\right)$ ditolak atau tidak terbukti kebenarannya.

Berdasarkan Tabel 3, dapat pula dijelaskan hasil uji hipotesis secara simultan (uji $F$ ). Untuk hubungan simultan antara profitabilitas, ukuran perusahaan dan financial leverage terhadap praktik perataan laba diperoleh nilai $F_{\text {hitung }}$ sebesar 3,061 dan tingkat signifikansi (Sig. $t$ ) sebesar 0,456. Karena nilai Sig. t lebih kecil dari 0,05 $(\alpha)$ maka $\mathrm{H}_{\mathrm{o}}$ ditolak dan $\mathrm{H}_{\mathrm{a}}$ diterima. Hasil ini menunjukkan terdapat pengaruh simultan yang signifikan oleh profitabilitas, ukuran perusahaan dan financial leverage terhadap praktik perataan laba. Dengan demikian, hipotesis keempat $\left(\mathrm{H}_{4}\right)$ diterima atau terbukti kebenarannya.

Selanjutnya, berdasarkan Tabel 2 dapat dipaparkan nilai koefisien determinasi $\left(\mathrm{R}^{2}\right)$ untuk model penelitian ini. Pada Tabel 2 tersebut dapat terlihat dari kolom Adjusted $R$ Square diperoleh nilai koefisien determinasi sebesar 0,137 atau $13,7 \%$. Hasil ini meunjukkan bahwa profitabilitas, ukuran perusahaan, dan financial leverage dapat menjelaskam variabilitas dari praktik perataan laba sebesar $13,7 \%$ dan sisanya dipengaruhi oleh variabel independen lain yang tidak digunakan dalam model penelitian ini, seperti harga saham, leverage operasi, struktur kepemilikan. 
Tabel 3. Hasil Uji $F$

\begin{tabular}{c|r|r|r|r|r}
\hline Model & R & R Square & Adjusted R Square & \multicolumn{1}{|c|}{$\begin{array}{c}\text { Std. Error of the } \\
\text { Estimate }\end{array}$} & Durbin-Watson \\
\hline 1 &, $451^{\mathrm{a}}$ &, 203 &, 137 & 56,61202 & 1,818 \\
\hline
\end{tabular}

Sumber: Data sekunder (diolah), Tahun 2017.

\section{KESIMPULAN}

Berdasarkan hasil analisis penelitian yang telah dilakukan, ditarik beberapa kesimpulan. Pertama, profitabilitas terbukti berpengaruh secara positif namun tidak signifikan terhadap praktik perataan laba, dan karenanya hipotesis 1 ditolak. Kedua, ukuran perusahaan terbukti berpengaruh secara positif dan signifikan terhadap praktik perataan laba, dan karenanya hipotesis 2 diterima. Ketiga, financial leverage terbukti berpengaruh secara negatif tetapi tidak signifikan terhadap praktik perataan laba, dan karenanya hipotesis 3 ditolak. Keempat, berdasarkan hasil pengujian secara simultan diperoleh profitabilitas, ukuran perusahaan, dan financial leverage tidak berpengaruh signifikan terhadap praktik perataan laba, dan dengan demikian hipotesis 4 ditolak. Lebih jauh, berdasarkan pengujian secara parsial diperoleh hanya ukuran perusahaan yang merupakan variabel yang secara signifikan mempengaruhi praktik perataan laba.

Berlandaskan kesimpulan tersebut, maka saran-saran yang dapat diberikan adalah sebagai berikut. Pertama, investor seharusnya memperhatikan ukuran perusahaan karena dalam penelitian ini menunjukkan bahwa aktiva yang besar, maka perusahaan melakukan praktik perataan laba. Kedua, penelitian selanjutnya diharapkan memakai periode penelitian yang lebih panjang, sehingga diperoleh hasil yang komprehensif dari penelitian-penelitian terdahulu. Terakhir, bagi penelitian selanjutnya direkomendasikan menggunakan variabel lain seperti harga saham, operating leverage ataupun struktur kepemilikan.

\section{DAFTAR PUSTAKA}

Adiningsih, M. 2014. Pengaruh Profitabilitas, Leverage Operasi, dan Ukuran Perusahaan terhadap Praktik Perataan
Laba. Jurnal Ilmu dan Riset Akuntansi. Vol. 3, No. 6, hal. 1-16.

Aji, D.Y. dan Mita, A.F. 2010. Pengaruh Profitabilitas, Risiko Keuangan, Nilai Perusahaan, dan Struktur Kepemilikan terhadap Praktek Perataan Laba: Studi Empiris Perusahaan Manufaktur yang Terdaftar di BEI. Prosiding. Simposium Nasional Akuntansi XIII Purwokerto.

Belkaoui, A. 2006. Teori Akuntansi. Edisi Kelima. Jakarta: Salemba Empat.

Budiasih, I.G.A.N. 2009. Faktor-Faktor yang Mempengaruhi Praktik Perataan Laba. Jurnal Ilmiah Akuntansi dan Bisnis. Vol. 4, No. 1, hal. 59-72.

Dewi, K.S. dan Pasetiono. 2012. Analisis Pengaruh ROA, NPM, DER dan Size terhadap Praktik Perataan Laba (Studi Kasus pada Perusahaan Manufaktur yang Terdaftar di Bursa Efek Indonesia Periode 2007-2010). Diponegoro Journal of Management. Vol. 1, No. 4, hal.172-180.

Ghozali, I. 2016. Aplikasi Analisis Multivariate dengan Program IBM SPSS 21 Update PLS Regresi. Edisi 7. Semarang: BP Undip.

Salno, H.M. dan Baridwan, Z. 2000. Analisis Perataan Penghasilan (Income Smoothing): Faktor-Faktor yang Mempengaruhi dan Kaitannya dengan Kinerja Saham Perusahaan Publik di Indonesia. Jurnal Riset Akuntansi Indonesia. Vol. 3, No.1, hal. 17-34.

Sartono, A.R. 2010. Manajemen Keuangan: Teori dan Aplikasi. Edisi Keempat. Yogyakarta: BPFE.

Sudana, I.M. 2011. Manajemen Keuangan Perusahaan: Teori dan Praktik. Jakarta: Penerbit Erlangga. 
Sugiyono. 2011. Metode Penelitian Kuantitatif Kualitatif dan R\&D. Bandung: CV. Alfabeta.

Suryandani, N.N. 2012. Analisis FaktorFaktor yang Mempengaruhi Income Smoothing. Media Komunikasi FIS. Vol. 11, No. 1, hal. 1-5.
Suwito, E. dan Herawaty, A. 2005. Analisis Pengaruh Karakteristik Perusahaan terhadap Tindakan Perataan Laba yang dilakukan oleh Perusahaan yang Terdaftar Di Bursa Efek Jakarta. Prosiding. Simposium Nasional Akuntansi VIII Solo, tanggal 15-16 September. 